professor of physies and chairman of the Department of Physics of Washington University, St. Louis, Mo., in succession to Prof. George E. Pake, who has been appointed to the chair of physics at Stanford University. Dr. Condon was previously director of research and development of the Corning Glass Works during 1951-55, and before that was director of the National Bureau of Standards, Washington, D.C. In 1953 he was president of the American Association for the Advancement of Science. Two other appointments in the Department of Physics have also been made : Dr. M. W. Friedlander, of the University of Bristol, England, to be a research associate with the task of establishing a nuclear emulsion group for the study of high-energy nuclear processes; and E. B. D. Lambe, of Princeton University and the University of British Columbia, whose speciality is paramagnetic resonance, to be assistant professor of physics.

\section{University of Durham}

THE University of Durham has announced the following appointments : Dr. W. B. Fisher, reader in geography, to the professorship of geography in the Durham Division; Dr. P. L. Robinson, reader in inorganic chemistry, to a personal professorship of inorganic chemistry in the Newcastle Division; Dr. E. G. Richardson, reader in physics, to a personal professorship of acoustics in the Newcastle Division ; Dr. J. Weiss, reader in the mechanism of chemical reactions, to a personal professorship of radiation chemistry in the Newcastle Division.

\section{Falkland Islands Geological Work at Birmingham}

A contract has been concluded between the Colonial Office and the University of Birmingham, as a result of which the geological work of the Falkland Islands Dependencies Scientific Bureau (the director of which is Sir Raymond Priestley) will for the next three years be done in the Department of Geology at Birmingham. The primary object of this arrangement is the production of a basic geological map and evaluation of the stratigraphy and economic resources of the Dependencies. Field work in the antarctic will continue as before, under the control of the Governor of the Falkland Islands. At Birmingham, the facilities of apparatus, comparison material and library will be made available to holders of newly established fellowships, some of whom will be appointed to deal with petrological and palæontological collections already made, while others will be men who have returned from a tour of field work and will require a further year or two years to work out their results. To co-ordinate this work, the University has appointed, under the title of Senior Research Fellow in the Department of Geology, Dr. R. J. Adie, who has, among other qualifications for this position, several years of practical experience in the Dependencies, and a number of publications on their geology.

\section{Training B.B.C. Engineers}

Prior to 1946, technical training within the British Broadcasting Corporation was carried on in a number of regional studio centres and at some of the large transmitting stations. It was then found necessary to centralize engineering training at Wood Norton Hall, near Evesham, in a special department, which has just passed its tenth anniversary. The head of this B.B.C. Engineering Training Department is Dr. K. R. Sturley, formerly assistant principal of Marconi College, Chelmsford. With the completion of some new buildings this year, about two hundred students can be accommodated on full-time residential courses of training, which cover both sound and television broadcasting. Every effort is made to avoid duplicating the training in electrical engineering given in universities and technical colleges; but the application of basic principles to the equipment and methods used by the B.B.C. is studied in detail. While radio engineering normally calls for a very high standard of mathematics and technical knowledge, a feature of the B.B.C. courses is the selection and presentation of special instruction in broadcasting engineering so that it can be readily understood by staff without advanced mathematical knowledge. This involves the use of special demonstration equipment, most of which is constructed in the department's laboratories and worksheps.

The various courses cover such subjects as sound recording, acoustics, studio lighting, and transmitters and aerial design for various frequencies. The courses vary in length up to twelve weeks, terminating in examinations, and the successful candidates are then eligible for promotion. A series of booklets, entitled "Engineering Training Supplements", have been prepared by the staff, dealing with such subjects as the principles of television lighting, audio-frequency amplifiers and frequency modulation; and these are used to augment the lectures and demonstrations. In the past ten years, nearly four thousand men and women have passed through the Department; and during 1956 the number attending the various courses is expected to rise to more than eight hundred.

\section{Industrial Trade Associations in Great Britain}

IN a broadsheet issued last year (Planning, 21, No. 383; 1955), Political and Economic Planning presents a preliminary account of a now survey of manufacturers' trade associations which is being conducted in co-operation with industry. It excludes associations concerned solely with research or with labour or management and also general bodies which represent industry as a whole, and, in addition, it excludes associations consisting entirely of distributors. Besides an analysis of the services offered by associations to their members, the inquiry attempts to assess the effectiveness of trade associa. tions' activities in representing members from the point of view of various bodies which have contacts with such associations, and it is also intended to approach many manufacturing firms to discover what trade associations mean to them in the course of their business. There appear now, in 1955, to be more than a thousand such associations in existence ; of these, more than two hundred are concerned with the textile and clothing industries and more than a hundred with each of the following industries: chemicals and allied trades; metal manufacturers; metal goods; engineering and shipbuilding; and food, drink and tobacco. Two main types of general, broadly based associations covering many specific interests can be distinguished : the federation comprising local or product associations, such as the British Man-Made Fibres Federation and the Wool Textile Delegation; and the large industry-wide association which may or may not have local or product associations affiliated to it, of which the British Electrical and Allied Manufacturers Association is an example. The broadsheet lists some thirty. seven different activities undertalken by some or other associations and reviews briefly the three main aspects of their work : representation of the industry; provision of common services (including exchange of 